\title{
Reproducibility of global electrical heterogeneity measurements on 12-lead ECG: The Multi-Ethnic Study of Atherosclerosis
}

Kazi T. Haq ${ }^{1}$, PhD, Katherine J. Lutz ${ }^{1}$, MD, Kyle Peters ${ }^{1}$, MD, Natalie Craig ${ }^{1}$, BS, Evan Mitchell $^{1}$, BS, Anish K. Desai ${ }^{1}$, MD, Nathan W. L. Stencel ${ }^{1}$, BS, Elsayed Z. Soliman ${ }^{2}$, MD, MSc, MS, João A.C. Lima ${ }^{3}, \mathrm{MD}, \mathrm{MBA}$, Larisa G. Tereshchenko ${ }^{1,3}$, MD, PhD.

${ }^{1}$ Knight Cardiovascular Institute, Oregon Health \& Science University, Portland, OR;

${ }^{2}$ Epidemiological Cardiology Research Center, Division of Public Health Sciences and Department of Medicine, Cardiology Section, Wake Forest School of Medicine, Winston Salem, NC; ${ }^{3}$ Cardiovascular Division, Department of Medicine, Johns Hopkins School of Medicine, Baltimore, MD.

Correspondence: Larisa Tereshchenko, 3181 SW Sam Jackson Park Rd; UHN62; Portland, OR, 97239. E-mail:tereshch@ohsu.edu.

\section{Brief Title: GEH reproducibility in MESA}

MESA pen draft AM 084 has been approved 6/7/21.

Words:6169 
medRxiv preprint doi: https://doi.org/10.1101/2021.06.07.21258521; this version posted June 11, 2021. The copyright holder for this preprint (which was not certified by peer review) is the author/funder, who has granted medRxiv a license to display the preprint in perpetuity.

\begin{abstract}
Objective - Vectorcardiographic (VCG) global electrical heterogeneity (GEH) metrics showed clinical usefulness. We aimed to assess the reproducibility of GEH metrics.

Methods-GEH was measured on two 10-second 12-lead ECGs recorded on the same day in

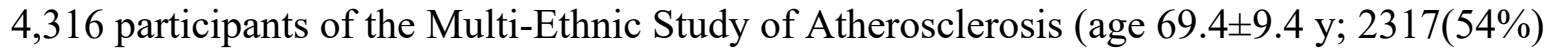
female, 1728 (40\%) white, 1138(26\%) African-American, 519(12\%) Asian-American, 931(22\%) Hispanic-American). GEH was measured on a median beat, comprised of the normal sinus (N), atrial fibrillation/flutter (S), and ventricular-paced (VP) beats. Spatial ventricular gradient's (SVG's) scalar was measured as sum absolute QRST integral (SAIQRST) and vector magnitude QT integral (VMQTi).
\end{abstract}

Results - Two N ECGs with heart rate (HR) bias of -0.64 (95\% limits of agreement [LOA] 5.68 to 5.21) showed spatial area QRS-T angle (aQRST) bias of -0.12 (95\%LOA -14.8 to 14.5). Two S ECGs with HR bias of 0.20 (95\%LOA -15.8 to 16.2) showed aQRST bias of 1.37 (95\%LOA -33.2 to 35.9). Two VP ECGs with HR bias of 0.25 (95\%LOA -3.0 to 3.5) showed aQRST bias of -1.03 (95\%LOA -11.9 to 9.9). After excluding premature arial or ventricular beat and two additional beats (before and after extrasystole), the number of cardiac beats included in a median beat did not affect the GEH reproducibility. Mean-centered log-transformed values of SAIQRST and VMQTi demonstrated perfect agreement (Bias 0; 95\%LOA -0.092 to 0.092).

Conclusion- GEH measurements on N, S, and VP median beats are reproducible. SVG's scalar can be measured as either SAIQRST or VMQTi.

Significance - Satisfactory reproducibility of GEH metrics supports their implementation.

Key words: global electrical heterogeneity; vectorcardiogram; reproducibility 
medRxiv preprint doi: https://doi.org/10.1101/2021.06.07.21258521; this version posted June 11, 2021. The copyright holder for this preprint (which was not certified by peer review) is the author/funder, who has granted medRxiv a license to display the preprint in perpetuity. All rights reserved. No reuse allowed without permission.

\section{Highlights}

- VCG metrics are reliably reproducible, which supports their implementation.

- GEH is reproducible if measured during atrial fibrillation or ventricular pacing.

- Scalar of spatial ventricular gradient can be measured as either SAIQRST or VMQTi. 
medRxiv preprint doi: https://doi.org/10.1101/2021.06.07.21258521; this version posted June 11, 2021. The copyright holder for this preprint (which was not certified by peer review) is the author/funder, who has granted medRxiv a license to display the preprint in perpetuity.

All rights reserved. No reuse allowed without permission.

\section{Introduction}

Vectorcardiographic (VCG) global electrical heterogeneity (GEH) metrics showed their clinical usefulness in heart failure patients with implanted primary prevention cardioverterdefibrillators[1-4] and in the general population.[5-10] GEH metrics represent comprehensive characterization of spatial ventricular gradient (SVG) magnitude, direction (azimuth and elevation), spatial QRS-T angle, and SVG's scalar value, sum absolute QRST integral (SAIQRST).[11, 12] Spatial QRS-T angle is a well-recognized and extensively studied marker of cardiovascular risk.[13] SVG defines a vector along which non-uniformity in excitation and repolarization is the most prominent.[14, 15] Wilson's frontal plane ventricular gradient was extended into three-dimensional (3D) SVG in 1954.[16, 17] The GEH concept is based on a strong scientific premise and more than 80 years of theoretical, experimental, and clinical investigations. Extensive previous studies support the need to implement GEH in clinical practice.[1-12, 18-24] For successful implementation in clinical practice, it is necessary to assess the reproducibility of GEH metrics.

A small preliminary study of GEH reproducibility was previously conducted using 5-min recordings of high-resolution $(1000 \mathrm{~Hz})$ ECG signals, comparing two randomly selected 10second segments.[25] However, the reproducibility of GEH measured on routine clinical 10second 12-lead ECG has not been studied. Moreover, it is unknown if there are differences in the reproducibility of GEH measured on the different types of median beat (normal sinus, atrial fibrillation, ventricular paced), and whether the number of beats included in a median beat and removal of a premature beat (either supraventricular or ventricular) affects reproducibility. To address these knowledge gaps, we conducted a comprehensive study of GEH reproducibility. We hypothesized that GEH measurements on 10-second 12-lead ECG are reproducible. 
medRxiv preprint doi: https://doi.org/10.1101/2021.06.07.21258521; this version posted June 11, 2021. The copyright holder for this preprint (which was not certified by peer review) is the author/funder, who has granted medRxiv a license to display the preprint in perpetuity.

All rights reserved. No reuse allowed without permission.

\section{Material and Methods}

\subsection{Study population}

We conducted an ancillary study in the Multi-Ethnic Study of Atherosclerosis (MESA).[26] All MESA participants signed informed consent before entering the MESA study. All MESA protocols were reviewed and approved by the local MESA field center IRBs. The current study protocol was approved by the Oregon Health \& Science University (OHSU) institutional review board.

MESA study participants had routine resting 12-lead ECG recorded during the first (years 2000-2002) and the fifth (years 2010-2011) study examinations. We aimed to assess the reproducibility of both normal sinus $(\mathrm{N})$ and abnormal types of median beats, including ventricular-paced (VP) and supraventricular (S, due to atrial fibrillation or atrial flutter) median beats. Therefore, we elected to analyze the data of the $5^{\text {th }}$ MESA examination that included older participants with a higher probability of having S and VP median beats. In the present study, we included MESA participants who had at least two 10-second resting 12-lead ECGs recorded consecutively during the $5^{\text {th }}$ examination. To be eligible for the reproducibility study, it was required to have at least two consecutive 10-second ECG recordings in the same rhythm (e.g., N and N, S and S, VP and VP). We excluded participants who did not have two consecutive 10second ECG recordings available, had a median beat other than N, S, or VP types, or the rhythm (and thus the median beat) changed between 2 consecutive ECG recordings.

\subsection{Theory, measurements, and calculation}

Twelve-lead digital ECGs were obtained by trained technicians using GE MAC 1200 electrocardiographs with standardized procedures. ECGs were transmitted electronically to the 
medRxiv preprint doi: https://doi.org/10.1101/2021.06.07.21258521; this version posted June 11, 2021. The copyright holder for this preprint (which was not certified by peer review) is the author/funder, who has granted medRxiv a license to display the preprint in perpetuity.

All rights reserved. No reuse allowed without permission.

MESA ECG Reading Center located at the Epidemiological Cardiology Research Center (Wake Forest School of Medicine, Winston-Salem, NC). According to MESA protocol, all filters in the ECG machines were disabled to provide unfiltered measurements. Initially, ECGs were automatically processed, after visual inspection for technical errors and inadequate quality, using the 2001 version of the GE Marquette 12-SL program.

For the purpose of this analysis, raw digital ECG signal was analyzed in the Tereshchenko laboratory at OHSU, as previously described.[7, 20, 27] Briefly, the analysis includes several steps. Each cardiac beat was manually labeled by at least two physician investigators (KJL, KP, EM, NC, AKD, NWLS, LGT). Then, 12-lead ECG was transformed into XYZ ECG, using a Kors transformation.[28] The origin of the heart vector was identified, and the time-coherent global median beat was constructed.[27] Only one (dominant) type of beat was included in the development of a median beat. This study included only three types of median beat: N, S, and VP. Ectopic beats (both atrial and ventricular premature beats) and two additional beats (the beat before and beat after ectopic beats) were excluded, and such fact was noted. We calculated the number of beats in a 10-second ECG recording and the number of beats included in the median beat.

Scalar values of SVG were measured by sum absolute QRST integral (SAIQRST) and by QT integral on vector magnitude (VM) signal (VMQTi).[20] Both area and peak QRS-T angles were measured.[7, 20,27] Quality control of automated ECG analysis was performed by the investigator $(\mathrm{KTH})$ with the aid of visual display. The open-source MATLAB (MathWorks, Natick, MA, USA) code is provided at https://physionet.org/physiotools/geh \& https://github.com/Tereshchenkolab/Origin. Figure 1 illustrates the VCG measurements. 
Spatial peak and spatial area QRS, T, and spatial ventricular gradient (SVG) vectors were constructed, and their direction (azimuth and elevation) and magnitudes were measured.[7, 20, 27] Spatial peak QRS and T vectors connected origin point with the furthest points away from the origin point in the QRS-loop and T-loop, respectively.

$t_{R}=\underset{t: t \in Q R S}{\arg \max }(V M(t))$

Spatial Peak QRS Azimuth $=\arctan \left(\frac{V z\left(t_{R}\right)}{V x\left(t_{R}\right)}\right)$

Spatial Peak QRS Elevation $=\arctan \left(\frac{V x\left(t_{R}\right)}{V y\left(t_{R}\right)}\right)$

Spatial Peak QRS Magnitude $=\sqrt{\left(V_{X}\left(t_{R}\right)\right)^{2}+\left(V_{Y}\left(t_{R}\right)\right)^{2}+\left(V_{Z}\left(t_{R}\right)\right)^{2}}$

$t_{T}=\underset{t: t \in T}{\arg \max }(V M(t))$

Spatial Peak T Azimuth $=\arctan \left(\frac{V z\left(t_{T}\right)}{V x\left(t_{T}\right)}\right)$

Spatial Peak T Elevation $=\arctan \left(\frac{V x\left(t_{T}\right)}{V y\left(t_{T}\right)}\right)$

Spatial Peak T Magnitude $=\sqrt{\left(V_{X}\left(t_{T}\right)\right)^{2}+\left(V_{Y}\left(t_{T}\right)\right)^{2}+\left(V_{Z}\left(t_{T}\right)\right)^{2}}$

Spatial Area $Q R S$ Azimuth $=\arctan \left(\frac{\int_{Q R S_{o n}}^{Q R S_{\text {off }}} V_{Z}(t) d t}{\int_{Q R S_{o n}}^{Q R S_{\text {off }}} V_{X}(t) d t}\right)$

Spatial Area $Q R S$ Elevation $=\arctan \left(\frac{\int_{Q R S_{o n}}^{Q R S_{\text {off }}} V_{X}(t) d t}{\int_{Q R S_{o n f}}^{Q R S_{\text {of }}} V_{Y}(t) d t}\right)$

$Q R S$ area $=\sqrt{\left(\int_{Q R S_{\text {on }}}^{Q R S_{\text {off }}} V_{x}(t) d t\right)^{2}+\left(\int_{Q R S_{\text {on }}}^{Q R S_{\text {off }}} V_{y}(t) d t\right)^{2}+\left(\int_{Q R S_{\text {on }}}^{Q R S_{\text {off }}} V_{Z}(t) d t\right)^{2}}$ 
Spatial Area $T$ Azimuth $=\arctan \left(\frac{\int_{Q R S_{\text {off }}}^{T_{\text {off }}} V_{Z}(t) d t}{\int_{Q R S_{\text {off }}}^{T_{\text {off }}} V_{X}(t) d t}\right)$

Spatial Area $T$ Elevation $=\arctan \left(\frac{\int_{Q R S_{o f f}}^{T_{o f f}} V_{X}(t) d t}{\int_{Q R S_{o f f}}^{T_{o f f}} V_{Y}(t) d t}\right)$

$T$ area $=\sqrt{\left(\int_{Q R S_{\text {off }}}^{T_{\text {off }}} V_{X}(t) d t\right)^{2}+\left(\int_{Q R S_{\text {off }}}^{T_{\text {off }}} V_{Y}(t) d t\right)^{2}+\left(\int_{Q R S_{\text {off }}}^{T_{\text {off }}} V_{Z}(t) d t\right)^{2}}$

Magnitude and direction of the spatial area and peak SVG vectors were measured.

$$
\begin{aligned}
& \overrightarrow{Q R S p e a k}=\overrightarrow{V M}\left(t_{R}\right) \text { and } \quad \overrightarrow{\text { Tpeak }}=\overrightarrow{V M}\left(t_{T}\right) \\
& \overrightarrow{S V G} \text { peak }=\overrightarrow{Q R S p e a k}+\overrightarrow{\text { Tpeak }} \\
& t_{S}=\underset{t: t \in Q R S T}{\arg \max }(S V(t)) \\
& \text { Spatial Peak SVG Azimuth }=\arctan \left(\frac{V_{Z}\left(t_{S}\right)}{V_{X}\left(t_{S}\right)}\right) \\
& \text { Spatial Peak SVG Elevation }=\arctan \left(\frac{V_{X}\left(t_{S}\right)}{V_{Y}\left(t_{S}\right)}\right)
\end{aligned}
$$

Spatial Peak SVG Magnitude $=\sqrt{\left(V_{X}\left(t_{S}\right)\right)^{2}+\left(V_{Y}\left(t_{S}\right)\right)^{2}+\left(V_{Z}\left(t_{S}\right)\right)^{2}}$

Spatial Area SVG Azimuth $=\arctan \left(\frac{\int_{Q R S_{o n}}^{T_{o f f}} V_{Z}(t) d t}{\int_{Q R S_{o n}}^{T_{o f f}} V_{X}(t) d t}\right)$

Spatial Area SVG Elevation $=\arctan \left(\frac{\int_{Q R S_{\text {on }}}^{T_{\text {off }}} V_{X}(t) d t}{\int_{Q R S_{\text {on }}}^{T} V_{Y}(t) d t}\right)$

$\|S V G\|=\sqrt{\left(\int_{Q R S_{o n}}^{T_{o f f}} V_{X}(t) d t\right)^{2}+\left(\int_{Q R S_{o n}}^{T_{o f f}} V_{Y}(t) d t\right)^{2}+\left(\int_{Q R S_{o n}}^{T_{o f f}} V_{Z}(t) d t\right)^{2}}$ 


$$
\begin{aligned}
& \text { Spatial peak } Q R S-T \text { angle }=\arccos \left(\frac{\overrightarrow{\text { QRSpeak }} \cdot \overrightarrow{T p e a k}}{\mid \text { QRSpeak }|| \text { Tpeak } \mid}\right) \\
& \text { Spatial area } Q R S-T \text { angle }=\arccos \left(\frac{\overline{\text { QRSarea }} \cdot \overline{T a r e a}}{\mid \text { QRSarea }|| \text { Tarea } \mid}\right) \\
& S A I Q R S T=\int_{Q R S_{\text {onset }}}^{T_{\text {offet }}}\left|V_{X}(t)\right| d t+\int_{Q R S_{\text {onset }}}^{T_{\text {offet }}}\left|V_{Y}(t)\right| d t+\int_{Q R S_{\text {onset }}}^{T_{\text {offset }}}\left|V_{Z}(t)\right| d t \\
& \|V M\|=\sqrt{Q R S T V_{X}^{2}+Q R S T V_{Y}^{2}+Q R S T V_{Z}^{2}} \\
& V M Q T_{i}=\int_{Q R S o n}^{T o f f}\|V M\| d t
\end{aligned}
$$

The reproducibility of the measurements on two consecutive 10-second ECGs was assessed by Bland-Altman analysis.[29, 30] The degree of the agreement was expressed as the bias (the mean difference) with $95 \%$ limits of agreement [mean \pm 2 standard deviations(SD)], and relative bias (the mean difference of two measurements divided by their mean value). Precision was defined as $100 \%$ minus relative $\%$ bias.

Coefficient of variation (CV) was calculated as the ratio of the SD of residuals (RMSE) after fitting linear regression between ECG1 and ECG2 variables to the sample mean of the ECG1 variable, and then multiplied by 100 to express it in terms of a percentage. CV assesses the variability around the regression line relative to the mean of ECG1 variable.

Interclass correlation coefficient (ICC), equal to Cronbach's alpha statistic,[31] was calculated for standardized variables (in the scale to mean 0 and variance 1).

The circular SVG azimuth variables range from $-180^{\circ}$ to $+180^{\circ}$. Thus, to calculate relative bias, CV, and ICC, SVG azimuth variables were transformed by doubling their value and adding 360. 
medRxiv preprint doi: https://doi.org/10.1101/2021.06.07.21258521; this version posted June 11, 2021. The copyright holder for this preprint (which was not certified by peer review) is the author/funder, who has granted medRxiv a license to display the preprint in perpetuity.

All rights reserved. No reuse allowed without permission.

The statistical correlation between pairs for each parameter was calculated as Pearson's correlation coefficient $r$. In addition, Lin's concordance correlation coefficient $\rho_{\mathrm{c}}$ (rho_c) was calculated to describe the strength of agreement: $>0.99$ indicated almost perfect agreement; $0.95-$ 0.99, substantial agreement; 0.90-0.95, moderate agreement; $<0.90$, poor agreement.

Furthermore, the Bradley-Blackwood procedure was used to compare the means and variances of the 2 measurements simultaneously.[32]

To confirm that SAIQRST and VMQTi are essentially the same, we assessed the agreement between SAIQRST and VMQTi measured on the same ECG\#1. We used mean-centered values of log-transformed SAIQRST and VMQTi, because of expected differences in their absolute values. The mean-centered value was obtained by subtracting the mean of the variable from each individual observation.

We compared the reproducibility of (1) three types of a median beat (N, S, VP), (2), and (4) on $\mathrm{N}$ median beat comprised of $\leq 6$ beats, $7-9$ beats, and $\geq 10$ beats. Statistical analysis was conducted using STATA MP 16.1 (StataCorp LP, College Station, TX). Open-source STATA code was provided at https://github.com/Tereshchenkolab/statistics.

\section{Results}

\subsection{Study population}

The study flowchart is shown in Figure 2. After excluding the MESA study participants who did not meet the inclusion criteria, the study population included 4,316 participants.

Demographic characteristics are shown in Table 1. The vast majority of participants had N median beats $(n=4228 ; 98.0 \%)$, whereas only few had S median beats $(n=68 ; 1.5 \%)$ and VP median beats $(n=20 ; 0.5 \%)$. As expected, participants with $\mathrm{N}$ median beats were younger than 
medRxiv preprint doi: https://doi.org/10.1101/2021.06.07.21258521; this version posted June 11, 2021. The copyright holder for this preprint (which was not certified by peer review) is the author/funder, who has granted medRxiv a license to display the preprint in perpetuity.

All rights reserved. No reuse allowed without permission.

those with S or VP median beats. Among participants with N median beats, $54 \%$ were female, and $40 \%$ were white.

\subsection{Reproducibility of GEH}

Reproducibility of the GEH metrics measured on two consecutive 10-second ECGs on a normal sinus median beat ranged between perfect and substantial (Table 2), and relative bias was less than 1\% for all GEH metrics. GEH measured on VP and S median beats was slightly less reproducible, ranging between substantial and moderate, and the relative bias was less than 5\% for all GEH metrics. For most VCG metrics, 95\% limits of agreement were similar for N and VP median beats (Figure 3) but were more prominent for $\mathrm{S}$ median beats.

Complete exclusion of ECG recordings with previously excluded PVCs or PACs did not have a noticeable effect on the reproducibility of GEH metrics (Table 2). Overall, 95\% limits of agreement were similar for all $\mathrm{N}$ median beats, regardless of the number of beats included in the template (Figure 3 and Table 4). There were no differences in GEH reproducibility in sex and race/ethnicity subgroups (data not shown).

\subsection{Agreement between SAIQRST and VMQTi.}

Mean-centered log-transformed values of SAIQRST and VMQTi measured on the same ECG demonstrated perfect agreement. Bias was equal to zero with 95\% limits of agreement from -0.092 to 0.092 (Figure 4$)$.

\section{Discussion}

In this large study of more than 4,000 MESA participants with two consecutive routine clinical 12-lead ECG recordings, we observed high reproducibility of VCG metrics measured on several types of median beat: N, S, and VP. This is an important finding, confirming that GEH 
medRxiv preprint doi: https://doi.org/10.1101/2021.06.07.21258521; this version posted June 11, 2021. The copyright holder for this preprint (which was not certified by peer review) is the author/funder, who has granted medRxiv a license to display the preprint in perpetuity.

All rights reserved. No reuse allowed without permission.

can be reproducibly measured not only during normal sinus rhythm but also during atrial fibrillation, atrial flutter, or ventricular pacing. After exclusion of either atrial or ventricular extrasystole and two additional beats (beats before and after an ectopic beat), the number of normal sinus cardiac beats included in the construction of $\mathrm{N}$ median beat did not affect the reproducibility of GEH metrics. In addition, this study confirmed that SVG's scalar metric could be measured as either SAIQRST or VMQTi, as mean-centered log-transformed values of SAIQRST and VMQTi are nearly identical.

Satisfactory reproducibility of a biomarker is an important requirement for its clinical and research use. The biomedical research community set off alarm bells about the reproducibility crisis.[33] In response, our study assessed the reproducibility of GEH measured on two 10second ECG recordings, mimicking a common clinical scenario. Knowledge about 95\% limits of agreement is essential for the appropriate interpretation of any given measurement. Importantly, as ECG metrics are heart rate-dependent, the reproducibility of ECG metrics should therefore be considered within the context of heart rate. For example, we observed that if a heart rate on two ECG differed by 5-6 bpm, area QRS-T angle differed by 15 degrees. If a heart rate on 2 ECGs differed by $\sim 16$ bpm (e.g., atrial fibrillation), area QRS-T angle differed by $\sim 36$ degrees. Both measurement error and physiological effect of heart rate differences contribute to the degree of agreement between ECG measurements on two 10-second ECGs.

Only few and mostly small previous studies assessed the reproducibility of ECG biomarkers.[34-39] The earlier small ( $n=253)$ GEH reproducibility study included primarily African Americans, performed only $\mathrm{N}$ median beat analysis, and demonstrated similar findings to the current study.[25] In two random 10-second ECG segments selected in 5-minute ECG recording, a heart rate differed by $\sim 5 \mathrm{bpm}$, and spatial QRS-T angle differed by $\sim 13$ degrees. 
medRxiv preprint doi: https://doi.org/10.1101/2021.06.07.21258521; this version posted June 11, 2021. The copyright holder for this preprint (which was not certified by peer review) is the author/funder, who has granted medRxiv a license to display the preprint in perpetuity.

All rights reserved. No reuse allowed without permission.

Notably, in the current study, we reported GEH reproducibility on abnormal median beats (S and VP) for the first time.

A previous study of the reproducibility of automated 12-lead ECG measurement[30] showed that the agreement for QRS duration measured on a global median beat ( $95 \%$ limits of agreement $\pm 9 \mathrm{~ms}$ ) was better than for QRS duration measured on a median beat of each individual ECG lead (95\% limits of agreement $\sim 13 \mathrm{~ms})$. Interestingly, relative bias was especially high ( $3 \%)$ for T wave amplitude measured on individual leads V1-V4 on an N median beat.[30] In contrast, in the current study, the relative bias for VCG magnitudes measured on a global time-coherent $\mathrm{N}$ median beat was less than $1 \%$, supporting the importance of an appropriate VCG's origin point detection.[27]

Young et al. [40] conducted a simulation study and investigated the effect of inaccuracies in $\mathrm{QRS}_{\text {onset, }} \mathrm{QRS}_{\text {offset}}$, and $\mathrm{T}_{\text {offset }}$ detection on spatial QRS-T angle. They observed the mean absolute error up to $~ 30$ degrees, which was slightly larger than the $95 \%$ limits of agreement observed in the current study (up to \pm 22 degrees). Furthermore, it is important to consider differences in signal processing approach between the two studies: Young et al. [40] (1) applied a $0.5-45 \mathrm{~Hz}$ bandpass filter that can modulate QRST morphology, (2) excluded from analysis ECGs with small T-wave amplitudes (if maximum T/QRS $<0.1$ ), and (3) defined VCG's origin point .at the beginning of QRS complex. We agree that the approach of Young et al. [40] is a reasonable approach for fully automated measurements. However, physiologically, PR interval reflects atrial repolarization, which is an electrically active phase frequently responsible for heart vector deviation and does not meet the definition of electrical quiescence. Moreover, the filter's low-pass band of $45 \mathrm{~Hz}$ significantly affects the amplitudes and morphology of the QRS complex. 
medRxiv preprint doi: https://doi.org/10.1101/2021.06.07.21258521; this version posted June 11, 2021. The copyright holder for this preprint (which was not certified by peer review) is the author/funder, who has granted medRxiv a license to display the preprint in perpetuity.

All rights reserved. No reuse allowed without permission.

In addition, this study confirmed that either SAIQRST or VMQTi could be used to quantify SVG's scalar, as the mean-centered log-transformed values of these two variables were nearly identical. Relative bias and 95\% limits of agreement were smaller for VMQTi than SAIQRST, suggesting that the reproducibility of VMQTi is slightly superior than SAIQRST. Only two fiducial points $\left(\mathrm{QRS}_{\text {onset }}\right.$ and $\left.\mathrm{T}_{\mathrm{offset}}\right)$ are required for VMQTi measurement, whereas six fiducial points $\left(\mathrm{QRS} \mathrm{onset}_{\text {and }} \mathrm{T}_{\text {offset }}\right.$ on $3 \mathrm{XYZ}$ leads) are required for SAIQRST measurements, thus increasing the probability of error.

\section{Conclusions}

VCG GEH measurements on a 10-second resting clinical ECG in participants with normal sinus rhythm, atrial fibrillation/flutter, or ventricular pacing are reproducible. After excluding a premature ectopic beat and two additional beats (before and after extrasystole), the number of cardiac beats included in a median beat template does not affect the reproducibility of VCG GEH measurements. The high reproducibility of GEH measurements supports their implementation in clinical practice and research.

\section{Acknowledgments}

This research was supported by contracts 75N92020D00001, HHSN268201500003I, N01HC-95159, 75N92020D00005, N01-HC-95160, 75N92020D00002, N01-HC-95161, 75N92020D00003, N01-HC-95162, 75N92020D00006, N01-HC-95163, 75N92020D00004, N01-HC-95164, 75N92020D00007, N01-HC-95165, N01-HC-95166, N01-HC-95167, N01-HC95168 and N01-HC-95169 from the National Heart, Lung, and Blood Institute, and by grants UL1-TR-000040, UL1-TR-001079, and UL1-TR-001420 from the National Center for

Advancing Translational Sciences (NCATS). The authors thank the other investigators, the staff, 
medRxiv preprint doi: https://doi.org/10.1101/2021.06.07.21258521; this version posted June 11, 2021. The copyright holder for this preprint (which was not certified by peer review) is the author/funder, who has granted medRxiv a license to display the preprint in perpetuity. All rights reserved. No reuse allowed without permission.

and the participants of the MESA study for their valuable contributions. A full list of

participating MESA investigators and institutions can be found at http://www.mesa-nhlbi.org.

\section{Funding}

This work was supported by the National Institutes of Health (HL118277), Medical Research Foundation of Oregon, and OHSU President Bridge funding (Tereshchenko), the National Center for Advancing Translational Sciences of the National Institutes of Health (UL1TR001420) (Soliman). 
medRxiv preprint doi: https://doi.org/10.1101/2021.06.07.21258521; this version posted June 11, 2021. The copyright holder for this preprint (which was not certified by peer review) is the author/funder, who has granted medRxiv a license to display the preprint in perpetuity.

\section{References:}

[1] L.G. Tereshchenko, A. Cheng, B.J. Fetics, J.E. Marine, D.D. Spragg, S. Sinha, H. Calkins,

G.F. Tomaselli, R.D. Berger, Ventricular arrhythmia is predicted by sum absolute QRST integral but not by QRS width, J Electrocardiol. 43 (2010) 548-552,

https://doi.org/10.1016/j.jelectrocard.2010.07.013

[2] L.G. Tereshchenko, A. Cheng, B.J. Fetics, B. Butcher, J.E. Marine, D.D. Spragg, S. Sinha, D.

Dalal, H. Calkins, G.F. Tomaselli, R.D. Berger, A new electrocardiogram marker to identify

patients at low risk for ventricular tachyarrhythmias: sum magnitude of the absolute QRST

integral, J Electrocardiol. 44 (2011) 208-216, https://doi.org/10.1016/j.jelectrocard.2010.08.012

[3] L.G. Tereshchenko, S. McNitt, L. Han, R.D. Berger, W. Zareba, ECG marker of adverse

electrical remodeling post-myocardial infarction predicts outcomes in MADIT II study, PLoS

One. 7 (2012) e51812, https://doi.org/10.1371/journal.pone.0051812

[4] J.W. Waks, K.T. Haq, C. Tompkins, A.J. Rogers, A. Ehdaie, A. Bender, J. Minnier, K.

Dalouk, S. Howell, A. Peiris, M. Raitt, S.M. Narayan, S.S. Chugh, L.G. Tereshchenko,

Competing risks in patients with primary prevention implantable cardioverter-defibrillators:

Global Electrical Heterogeneity and Clinical Outcomes (GEHCO) study, Heart Rhythm.

10.1016/j.hrthm.2021.03.006 (2021), https://doi.org/10.1016/j.hrthm.2021.03.006

[5] J.W. Waks, C.M. Sitlani, E.Z. Soliman, M. Kabir, E. Ghafoori, M.L. Biggs, C.A. Henrikson,

N. Sotoodehnia, T. Biering-Sorensen, S.K. Agarwal, D.S. Siscovick, W.S. Post, S.D. Solomon,

A.E. Buxton, M.E. Josephson, L.G. Tereshchenko, Global Electric Heterogeneity Risk Score for

Prediction of Sudden Cardiac Death in the General Population: The Atherosclerosis Risk in

Communities (ARIC) and Cardiovascular Health (CHS) Studies, Circulation. 133 (2016) 2222-

2234, https://doi.org/10.1161/CIRCULATIONAHA.116.021306 
medRxiv preprint doi: https://doi.org/10.1101/2021.06.07.21258521; this version posted June 11, 2021. The copyright holder for this preprint (which was not certified by peer review) is the author/funder, who has granted medRxiv a license to display the preprint in perpetuity.

All rights reserved. No reuse allowed without permission.

[6] T. Biering-Sorensen, M. Kabir, J.W. Waks, J. Thomas, W.S. Post, E.Z. Soliman, A.E.

Buxton, A.M. Shah, S.D. Solomon, L.G. Tereshchenko, Global ECG Measures and Cardiac

Structure and Function: The ARIC Study (Atherosclerosis Risk in Communities), Circ Arrhythm

Electrophysiol. 11 (2018) e005961, https://doi.org/10.1161/CIRCEP.117.005961

[7] E.A. Perez-Alday, A. Bender, D. German, S.V. Mukundan, C. Hamilton, J.A. Thomas, Y. Li-

Pershing, L.G. Tereshchenko, Dynamic predictive accuracy of electrocardiographic biomarkers

of sudden cardiac death within a survival framework: the Atherosclerosis Risk in Communities

(ARIC) study, BMC cardiovascular disorders. 19 (2019) 255, https://doi.org/10.1186/s12872-

$\underline{019-1234-9}$

[8] S.J. Howell, D. German, A. Bender, F. Phan, S.V. Mukundan, E.A. Perez-Alday, N.M.

Rogovoy, K.T. Haq, K. Yang, A. Wirth, K. Jensen, L.G. Tereshchenko, Does sex modify an association of electrophysiological substrate with sudden cardiac death? The Atherosclerosis

Risk in Communities (ARIC) study, Cardiovascular Digital Health Journal. 1 (2020) 80-88, https://doi.org/10.1016/j.cvdhj.2020.08.003

[9] K. Jensen, S.J. Howell, F. Phan, M. Khayyat-Kholghi, L. Wang, K.T. Haq, J. Johnson, L.G. Tereshchenko, Bringing Critical Race Praxis Into the Study of Electrophysiological Substrate of Sudden Cardiac Death: The ARIC Study, J Am Heart Assoc. 9 (2020) e015012, https://doi.org/10.1161/JAHA.119.015012

[10] J.D. Pollard, K.T. Haq, K.J. Lutz, N.M. Rogovoy, K.A. Paternostro, E.Z. Soliman, J. Maher, J.A.C. Lima, S.K. Musani, L.G. Tereshchenko, Electrocardiogram machine learning for detection of cardiovascular disease in African Americans: the Jackson Heart Study, European Heart Journal - Digital Health. 2 (2021) 137-151, https://doi.org/10.1093/ehjdh/ztab003 
medRxiv preprint doi: https://doi.org/10.1101/2021.06.07.21258521; this version posted June 11, 2021. The copyright holder for this preprint (which was not certified by peer review) is the author/funder, who has granted medRxiv a license to display the preprint in perpetuity. All rights reserved. No reuse allowed without permission.

[11] L.G. Tereshchenko, A. Cheng, J. Park, N. Wold, T.E. Meyer, M.R. Gold, S. Mittal, J. Singh, K.M. Stein, K.A. Ellenbogen, SMART-AV Trial Investigators, Novel measure of electrical dyssynchrony predicts response in cardiac resynchronization therapy: Results from the SMARTAV Trial, Heart Rhythm. 12 (2015) 2402-2410, https://doi.org/10.1016/j.hrthm.2015.08.009 [12] J. Jacobsson, R. Borgquist, C. Reitan, E. Ghafoori, N.A. Chatterjee, M. Kabir, P.G. Platonov, J. Carlson, J.P. Singh, L.G. Tereshchenko, Usefulness of the Sum Absolute QRST Integral to Predict Outcomes in Patients Receiving Cardiac Resynchronization Therapy, Am J Cardiol. 118 (2016) 389-395, https://doi.org/10.1016/j.amjcard.2016.05.017

[13] A. Oehler, T. Feldman, C.A. Henrikson, L.G. Tereshchenko, QRS-T Angle: A Review, Ann Noninvasive Electrocardiol. 19 (2014) 534-542, https://doi.org/10.1111/anec.12206

[14] F.N. Wilson, A.G. Macleod, P.S. Barker, F.D. Johnston, The determination and the significance of the areas of the ventricular deflections of the electrocardiogram, American Heart Journal. 10 (1934) 46-61, https://doi.org/http://dx.doi.org/10.1016/S0002-8703(34)90303-3

[15] G.E. Burch, T. Winsor, A primer of electrocardiography, Lea \& Febiger, Philadelphia, 1945.

[16] G.E. Burch, A.A. Abildskov, J.A. Cronvich, A study of the spatial vectorcardiogram of the ventricular gradient, Circulation. 9 (1954) 267-275, http://www.ncbi.nlm.nih.gov/pubmed/13127188 http://circ.ahajournals.org/content/9/2/267.full.pdf

[17] E. Simonson, O.H. Schmitt, J. Dahl, D. Fry, E.E. Bakken, The theoretical and experimental bases of the frontal plane ventricular gradient and its spatial counterpart, American heart journal. 47 (1954) 122-153, https://doi.org/http://dx.doi.org/10.1016/0002-8703(54)90221-5 
medRxiv preprint doi: https://doi.org/10.1101/2021.06.07.21258521; this version posted June 11, 2021. The copyright holder for this preprint (which was not certified by peer review) is the author/funder, who has granted medRxiv a license to display the preprint in perpetuity. All rights reserved. No reuse allowed without permission.

[18] Z.M. Zhang, P.M. Rautaharju, R.J. Prineas, L. Tereshchenko, E.Z. Soliman, Electrocardiographic QRS-T angle and the risk of incident silent myocardial infarction in the Atherosclerosis Risk in Communities study, J Electrocardiol. 50 (2017) 661-666, https://doi.org/10.1016/j.jelectrocard.2017.05.001

[19] L.G. Tereshchenko, N. Sotoodehnia, C.M. Sitlani, F.N. Ashar, M. Kabir, M.L. Biggs, M.P. Morley, J.W. Waks, E.Z. Soliman, A.E. Buxton, T. Biering-Sorensen, S.D. Solomon, W.S. Post, T.P. Cappola, D.S. Siscovick, D.E. Arking, Genome-Wide Associations of Global Electrical Heterogeneity ECG Phenotype: The ARIC (Atherosclerosis Risk in Communities) Study and CHS (Cardiovascular Health Study), J Am Heart Assoc. 7 (2018) e008160, https://doi.org/10.1161/JAHA.117.008160

[20] J.A. Thomas, A.P.-A. E, A. Junell, K. Newton, C. Hamilton, Y. Li-Pershing, D. German, A. Bender, L.G. Tereshchenko, Vectorcardiogram in athletes: The Sun Valley Ski Study, Ann Noninvasive Electrocardiol. 24 (2019) e12614, https://doi.org/10.1111/anec.12614

[21] H.F. Stabenau, C. Shen, L.G. Tereshchenko, J.W. Waks, Changes in global electrical heterogeneity associated with dofetilide, quinidine, ranolazine, and verapamil, Heart Rhythm. 17 (2020) 460-467, https://doi.org/10.1016/j.hrthm.2019.09.017

[22] K.T. Haq, J. Cao, L.G. Tereshchenko, Characteristics of Cardiac Memory in Patients with Implanted Cardioverter-defibrillators: The Cardiac Memory with Implantable Cardioverterdefibrillator (CAMI) Study, J Innov Card Rhythm Manag. 12 (2021) 4395-4408, https://doi.org/10.19102/icrm.2021.120204

[23] J.D. Pollard, K.T. Haq, K.J. Lutz, N.M. Rogovoy, K.A. Paternostro, E.Z. Soliman, J. Maher, J.A. Lima, S. Musani, L.G. Tereshchenko, Sex differences in vectorcardiogram of African- 
medRxiv preprint doi: https://doi.org/10.1101/2021.06.07.21258521; this version posted June 11, 2021. The copyright holder for this preprint (which was not certified by peer review) is the author/funder, who has granted medRxiv a license to display the preprint in perpetuity.

All rights reserved. No reuse allowed without permission.

Americans with and without cardiovascular disease: a cross-sectional study in the Jackson Heart Study cohort, BMJ open. 11 (2021) e042899, https://doi.org/10.1136/bmjopen-2020-042899

[24] H.F. Stabenau, C. Shen, P. Zimetbaum, A.E. Buxton, L.G. Tereshchenko, J.W. Waks, Global electrical heterogeneity associated with drug-induced torsades de pointes, Heart Rhythm. 18 (2021) 57-62, https://doi.org/10.1016/j.hrthm.2020.07.038

[25] E. Perez-Alday, C. Hamilton, Y. Li-Pershing, J.M. Monroy-Trujillo, M. Estrella, S. Sozio, B. Jaar, R. Parekh, L.G. Tereshchenko The Reproducibility of Global Electrical Heterogeneity ECG Measurements, Computing in cardiology. 45 (2018) 162-166, https://doi.org/10.22489/CinC.2018.162

[26] D.E. Bild, D.A. Bluemke, G.L. Burke, R. Detrano, A.V. Diez Roux, A.R. Folsom, P.

Greenland, D.R. JacobsJr., R. Kronmal, K. Liu, J.C. Nelson, D. O’Leary, M.F. Saad, S. Shea, M. Szklo, R.P. Tracy, Multi-Ethnic Study of Atherosclerosis: Objectives and Design, American Journal of Epidemiology. 156 (2002) 871-881, https://doi.org/10.1093/aje/kwf113

[27] E.A. Perez-Alday, Y. Li-Pershing, A. Bender, C. Hamilton, J.A. Thomas, K. Johnson, T.L. Lee, R. Gonzales, A. Li, K. Newton, L.G. Tereshchenko, Importance of the heart vector origin point definition for an ECG analysis: The Atherosclerosis Risk in Communities (ARIC) study, Comput Biol Med. 104 (2019) 127-138, https://doi.org/10.1016/j.compbiomed.2018.11.013 [28] J.A. Kors, H.G. van, A.C. Sittig, J.H. van Bemmel, Reconstruction of the Frank vectorcardiogram from standard electrocardiographic leads: diagnostic comparison of different methods, Eur.Heart J. 11 (1990) 1083-1092, http://www.ncbi.nlm.nih.gov/pubmed/2292255 [29] J.M. Bland, D.G. Altman, Statistical methods for assessing agreement between two methods of clinical measurement, Lancet. 1 (1986) 307-310, http://www.ncbi.nlm.nih.gov/pubmed/2868172 
medRxiv preprint doi: https://doi.org/10.1101/2021.06.07.21258521; this version posted June 11, 2021. The copyright holder for this preprint (which was not certified by peer review) is the author/funder, who has granted medRxiv a license to display the preprint in perpetuity.

All rights reserved. No reuse allowed without permission.

[30] T. Huang, C.A. James, C. Tichnell, B. Murray, J. Xue, H. Calkins, L.G. Tereshchenko, Statistical evaluation of reproducibility of automated ECG measurements: an example from arrhythmogenic right ventricular dysplasia/cardiomyopathy clinic, Biomedical signal processing and control. 13 (2014) 23-30, https://doi.org/10.1016/j.bspc.2014.03.009

[31] G. Bravo, L. Potvin, Estimating the reliability of continuous measures with Cronbach's alpha or the intraclass correlation coefficient: toward the integration of two traditions, Journal of clinical epidemiology. 44 (1991) 381-390, https://doi.org/10.1016/0895-4356(91)90076-1

[32] E.L. Bradley, L.G. Blackwood, Comparing Paired Data: A Simultaneous Test for Means and Variances, The American Statistician. 43 (1989) 234-235, https://doi.org/10.1080/00031305.1989.10475665

[33] M. Baker, 1,500 scientists lift the lid on reproducibility, Nature. 533 (2016) 452-454, https://doi.org/10.1038/533452a

[34] D. Drager, E.Z. Soliman, M.L. Meyer, Z.M. Zhang, A. Alonso, G. Heiss, E.A. Whitsel, Short-term repeatability of the peguero-lo presti electrocardiographic left ventricular hypertrophy criteria, Ann Noninvasive Electrocardiol. 10.1111/anec.12829 (2021) e12829, https://doi.org/10.1111/anec.12829

[35] A. Feeny, L. Han, L.G. Tereshchenko, Repolarization lability measured on 10-second ECG by spatial TT' angle: reproducibility and agreement with QT variability, J Electrocardiol. 47 (2014) 708-715, https://doi.org/10.1016/i.jelectrocard.2014.06.003

[36] J. Caro-Codón, J.R. Rey, J. Díaz Cruz, L.A. Martínez Marín, J.M. García de Veas Marquéz, S. Castrejón, M. Martínez Cossiani, L. Rodríguez Sotelo, J.L. López-Sendón, J.L. Merino, Precision and reproducibility of non-automatic measurement of the QRS complex in potential 
medRxiv preprint doi: https://doi.org/10.1101/2021.06.07.21258521; this version posted June 11, 2021. The copyright holder for this preprint (which was not certified by peer review) is the author/funder, who has granted medRxiv a license to display the preprint in perpetuity.

All rights reserved. No reuse allowed without permission.

candidates for cardiac resynchronization therapy, J Electrocardiol. 57 (2019) 90-94, https://doi.org/10.1016/j.jelectrocard.2019.08.011

[37] C. Stephansen, M.B. Kronborg, C.T. Witt, J. Kristensen, C. Gerdes, A. Sommer, J.M.

Jensen, J.C. Nielsen, Reproducibility of measuring QRS duration and implications for optimization of interventricular pacing delay in cardiac resynchronization therapy, Ann

Noninvasive Electrocardiol. 24 (2019) e12621, https://doi.org/10.1111/anec.12621

[38] I. Jekova, V. Krasteva, R. Leber, R. Schmid, R. Twerenbold, C. Müller, T. Reichlin, R. Abächerli, Intersubject variability and intrasubject reproducibility of 12-lead ECG metrics:

Implications for human verification, J Electrocardiol. 49 (2016) 784-789, https://doi.org/10.1016/j.jelectrocard.2016.07.021

[39] G.M. Burke, N. Wang, S. Blease, D. Levy, J.W. Magnani, Assessment of reproducibility-automated and digital caliper ECG measurement in the Framingham Heart Study, J

Electrocardiol. 47 (2014) 288-293, https://doi.org/10.1016/j.jelectrocard.2014.01.004

[40] W.J. Young, S. van Duijvenboden, J. Ramirez, A. Jones, A. Tinker, P.B. Munroe, P.D. Lambiase, M. Orini, A Method to Minimise the Impact of ECG Marker Inaccuracies on the Spatial QRS-T angle: Evaluation on 1,512 Manually Annotated ECGs, Biomedical signal processing and control. 64 (2021) 102305, https://doi.org/10.1016/j.bspc.2020.102305 
medRxiv preprint doi: https://doi.org/10.1101/2021.06.07.21258521; this version posted June 11, 2021. The copyright holder for this preprint (which was not certified by peer review) is the author/funder, who has granted medRxiv a license to display the preprint in perpetuity. All rights reserved. No reuse allowed without permission.

Table 1. Demographic characteristics of the study participants

\begin{tabular}{llll}
\hline Characteristic & N beat $(\mathrm{n}=4228)$ & S beat $(\mathrm{n}=68)$ & VP beat $(\mathrm{n}=20)$ \\
\hline Age $(\mathrm{mean} \pm \mathrm{SD}), \mathrm{y}$ & $69.2 \pm 9.3$ & $77.5 \pm 8.3$ & $76.3 \pm 10.5$ \\
Women, $\mathrm{n}(\%)$ & $2291(54)$ & $21(31)$ & $5(25)$ \\
White, $\mathrm{n}(\%)$ & $1681(40)$ & $39(57)$ & $8(40)$ \\
African-American, $\mathrm{n}(\%)$ & $1121(27)$ & $12(18)$ & $5(25)$ \\
Asian-American, $\mathrm{n}(\%)$ & $517(12)$ & $2(3)$ & 0 \\
Hispanic-American, $\mathrm{n}(\%)$ & $909(22)$ & $15(22)$ & $7(35)$ \\
\hline
\end{tabular}


Table 2. Reproducibility agreement of GEH measurements on two 10-second ECG recordings, on $N$, S, and VP median beats.

\begin{tabular}{|c|c|c|c|c|c|c|c|c|c|c|c|c|}
\hline & Measurement & $\begin{array}{c}\text { ECG1 } \\
\text { mean }(\mathrm{SD})\end{array}$ & $\begin{array}{c}\text { ECG2 } \\
\text { mean }(\mathrm{SD})\end{array}$ & Bias & $\begin{array}{c}95 \% \text { Limits of } \\
\text { agreement }\end{array}$ & $\%$ bias & $\begin{array}{l}\text { Precision, } \\
\%\end{array}$ & $\mathrm{CV}, \%$ & $\mathrm{ICC}$ & $\operatorname{Lin} \rho_{c}(95 \% \mathrm{CI})$ & Pearson & $\begin{array}{l}\text { r } \quad \text { Bradley- } \\
\text { Blackwood F (P) }\end{array}$ \\
\hline \multirow{11}{*}{ 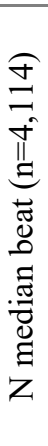 } & Heart rate, bpm & $61.5(9.4)$ & $61.8(9.4)$ & -0.64 & -5.68 to 5.21 & 0.34 & 99.66 & 4.5 & 0.978 & $0.956(0.953-0.959)$ & 0.956 & $14.9(<0.001)$ \\
\hline & Peak QRS-Tangle, ${ }^{\circ}$ & $44.1(36.4)$ & $44.2(36.6)$ & -0.05 & -21.2 to 21.1 & 0.08 & 99.92 & 24.1 & 0.978 & $0.956(0.954-0.959)$ & 0.956 & $1.27(0.281)$ \\
\hline & Area QRS-Tangle, ${ }^{\circ}$ & $64.3(34.7)$ & $64.4(34.9)$ & -0.12 & -14.8 to 14.5 & 0.19 & 99.81 & 11.5 & 0.988 & $0.977(0.976-0.978)$ & 0.977 & $2.55(0.078)$ \\
\hline & Peak SVG azimuth, ${ }^{\circ}$ & $-1.4(26.9)$ & $-1.2(26.8)$ & -0.11 & -18.5 to 18.3 & 0.07 & 99.93 & 5.2 & 0.968 & $0.939(0.935-0.942)$ & 0.939 & $0.758(0.469)$ \\
\hline & Area SVG azimuth, ${ }^{\circ}$ & $-17.5(25.9)$ & $-17.0(25.9)$ & -0.48 & -21.1 to 20.2 & 0.35 & 99.65 & 6.3 & 0.957 & $0.917(0.912-0.922)$ & 0.917 & $4.34(0.013)$ \\
\hline & Peak SVG elevation, ${ }^{\circ}$ & $71.0(14.4)$ & $71.0(14.1)$ & -0.04 & -6.80 to 6.72 & 0.07 & 99.93 & 4.9 & 0.985 & $0.970(0.969-0.972)$ & 0.971 & $16.8(<0.001)$ \\
\hline & Area SVG elevation, ${ }^{\circ}$ & $69.5(15.4)$ & $69.6(15.3)$ & -0.08 & -10.0 to 9.84 & 0.13 & 99.87 & 7.2 & 0.972 & $0.946(0.943-0.949)$ & 0.946 & $1.25(0.286)$ \\
\hline & Peak $\mathrm{SVG}_{\mathrm{mag}, \mathrm{mV}}$ & $1.56(0.45)$ & $1.56(0.45)$ & 0.001 & -0.21 to 0.21 & 0.06 & 99.94 & 6.8 & 0.986 & $0.971(0.970-0.973)$ & 0.971 & $0.09(0.918)$ \\
\hline & $\mathrm{SVG}, \mathrm{mV}^{*} \mathrm{~ms}$ & $66.8(27.0)$ & $66.6(26.9)$ & 0.14 & -11.5 to 11.8 & 0.24 & 99.76 & 8.8 & 0.988 & $0.976(0.974-0.977)$ & 0.976 & $1.38(0.253)$ \\
\hline & VMQTi, mV*ms & $96.7(30.7)$ & $96.7(30.5)$ & 0.10 & -8.96 to 9.15 & 0.13 & 99.87 & 4.8 & 0.994 & $0.989(0.988-0.989)$ & 0.989 & $3.80(0.022)$ \\
\hline & SAIQRST, $\mathrm{mV}^{*} \mathrm{~ms}$ & $146.7(46.9)$ & $146.5(46.6)$ & 0.23 & -14.6 to 15.1 & 0.20 & 99.80 & 5.2 & 0.993 & $0.987(0.986-0.988)$ & 0.987 & $4.97(0.007)$ \\
\hline \multirow{11}{*}{ 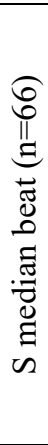 } & Heart rate, bpm & $73.6(16.3)$ & $73.4(16.3)$ & 0.20 & -15.8 to 16.2 & 0.24 & 99.76 & 10.8 & 0.933 & $0.874(0.803-0.921)$ & 0.875 & $0.02(0.980)$ \\
\hline & Peak QRS-Tangle, ${ }^{\circ}$ & $74.1(51.3)$ & $70.6(51.8)$ & 3.50 & -30.1 to 37.1 & 2.80 & 97.20 & 22.9 & 0.972 & $0.943(0.908-0.964)$ & 0.954 & $1.36(0.265)$ \\
\hline & Area QRS-Tangle, ${ }^{\circ}$ & $95.6(42.8)$ & $94.2(41.3)$ & 1.37 & -33.2 to 35.9 & 1.39 & 98.61 & 18.4 & 0.954 & $0.912(0.860-0.945)$ & 0.913 & $0.42(0.658)$ \\
\hline & Peak SVG azimuth, ${ }^{\circ}$ & $23.7(45.7)$ & $19.8(42.7)$ & 3.89 & -33.5 to 41.2 & 2.31 & 97.69 & 9.4 & 0.955 & $0.906(0.853-0.941)$ & 0.913 & $2.99(0.057)$ \\
\hline & Area SVG azimuth, ${ }^{\circ}$ & $17.9(50.5)$ & $17.1(50.5)$ & 0.71 & -34.6 to 35.0 & 1.25 & 98.75 & 9.0 & 0.967 & $0.936(0.898-0.960)$ & 0.936 & $0.05(0.950)$ \\
\hline & Peak SVG elevation, ${ }^{\circ}$ & $80.0(19.8)$ & $79.8(19.1)$ & 0.27 & -9.87 to 10.4 & 0.28 & 99.72 & 6.5 & 0.982 & $0.965(0.943-0.978)$ & 0.965 & $0.68(0.511)$ \\
\hline & Area SVG elevation, ${ }^{\circ}$ & $83.1(24.1)$ & $82.2(21.9)$ & 0.93 & -20.6 to 22.4 & 0.63 & 99.37 & 13.3 & 0.942 & $0.886(0.822-0.928)$ & 0.891 & $1.70(0.191)$ \\
\hline & Peak $\mathrm{SVG}_{\mathrm{mag}}, \mathrm{mV}$ & $1.23(0.45)$ & $1.25(0.45)$ & -0.02 & -0.21 to 0.17 & 1.89 & 98.11 & 7.9 & 0.989 & $0.976(0.961-0.985)$ & 0.977 & $2.08(0.133)$ \\
\hline & $\mathrm{SVG}, \mathrm{mV}^{*} \mathrm{~ms}$ & $40.9(17.9)$ & $42.3(18.4)$ & -1.43 & -17.1 to 14.3 & 2.81 & 97.19 & 19.0 & 0.949 & $0.900(0.842-0.937)$ & 0.903 & $1.17(0.318)$ \\
\hline & VMQTi, mV*ms & $84.6(34.0)$ & $84.7(34.6)$ & -0.06 & -11.9 to 11.8 & 0.05 & 99.95 & 7.1 & 0.992 & $0.985(0.975-0.990)$ & 0.985 & $0.28(0.759)$ \\
\hline & $\mathrm{SAIQRST}, \mathrm{mV}{ }^{*} \mathrm{~ms}$ & $126.2(53.5)$ & $125.7(54.6)$ & 0.55 & -20.1 to 21.2 & 0.30 & 99.70 & 8.2 & 0.991 & $0.981(0.969-0.988)$ & 0.981 & $0.50(0.609)$ \\
\hline \multirow{11}{*}{ 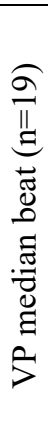 } & Heart rate, bpm & $66.8(5.4)$ & $66.5(5.3)$ & 0.25 & -3.0 to 3.5 & 0.35 & 99.65 & 2.5 & 0.953 & $0.952(0.880-0.981)$ & 0.953 & $0.26(0.771)$ \\
\hline & Peak QRS-Tangle, & $154.6(38.0)$ & $154.8(33.7)$ & -0.17 & -13.7 to 13.3 & 0.10 & 99.90 & 3.8 & 0.994 & $0.982(0.962-0.991)$ & 0.989 & $5.76(0.012)$ \\
\hline & Area QRS-Tangle, ${ }^{\circ}$ & $155.6(28.1)$ & $156.6(26.5)$ & -1.03 & -11.9 to 9.9 & 0.69 & 99.31 & 3.6 & 0.990 & $0.979(0.948-0.991)$ & 0.981 & $1.13(0.292)$ \\
\hline & Peak SVG azimuth, ${ }^{\circ}$ & $87.3(42.5)$ & $89.6(43.2)$ & -2.26 & -21.9 to 17.4 & 1.02 & 98.98 & 3.8 & 0.986 & $0.971(0.927-0.989)$ & 0.973 & $0.49(0.621)$ \\
\hline & Area SVG azimuth, ${ }^{\circ}$ & $53.9(67.6)$ & $62.8(76.8)$ & -8.88 & -64.4 to 46.7 & 4.47 & 95.53 & 10.9 & 0.964 & $0.916(0.806-0.965)$ & 0.931 & $2.03(0.162)$ \\
\hline & Peak SVG elevation, ${ }^{\circ}$ & $113.3(29.8)$ & $112.6(30.1)$ & 0.69 & -12.9 to 14.3 & 0.61 & 99.39 & 6.2 & 0.986 & $0.973(0.931-0.989)$ & 0.973 & $0.10(0.902)$ \\
\hline & Area SVG elevation, ${ }^{\circ}$ & $104.1(33.3)$ & $108.5(36.2)$ & -4.37 & -24.9 to 16.2 & 4.07 & 95.93 & 9.4 & 0.979 & $0.947(0.873-0.978)$ & 0.958 & $2.40(0.121)$ \\
\hline & Peak $\mathrm{SVG}_{\mathrm{mag}}, \mathrm{mV}$ & $0.95(0.25)$ & $0.98(0.25)$ & -0.03 & -0.14 to 0.08 & 2.92 & 97.08 & 5.9 & 0.988 & $0.970(0.925-0.988)$ & 0.977 & $2.54(0.108)$ \\
\hline & $\mathrm{SVG}, \mathrm{mV}^{*} \mathrm{~ms}$ & $45.4(25.7)$ & $45.4(27.9)$ & 0.03 & -14.0 to 14.1 & 0.06 & 99.94 & 14.7 & 0.984 & $0.964(0.914-0.985)$ & 0.967 & $0.90(0.425)$ \\
\hline & VMQTi, mV*ms & $194.9(86.6)$ & $193.7(88.7)$ & 1.18 & -18.4 to 20.7 & 0.71 & 99.29 & 5.1 & 0.997 & $0.993(0.983-0.997)$ & 0.994 & $0.54(0.593)$ \\
\hline & $\mathrm{SAIQRST}, \mathrm{mV}{ }^{*} \mathrm{~ms}$ & $298.5(132.4)$ & $297.1(135.4)$ & 1.41 & -26.7 to 29.5 & 0.51 & 99.49 & 4.8 & 0.997 & $0.994(0.985-0.998)$ & 0.995 & $0.465(0.64)$ \\
\hline
\end{tabular}


Table 3. Reproducibility agreement of GEH measurements on two 10-sec ECGs on $N$ beat without excluded premature beats.

\begin{tabular}{|c|c|c|c|c|c|c|c|c|c|c|c|c|}
\hline & Measurement & $\begin{array}{c}\text { ECG1 } \\
\text { mean }(\mathrm{SD})\end{array}$ & $\begin{array}{c}\text { ECG2 } \\
\text { mean }(\mathrm{SD})\end{array}$ & Bias & $\begin{array}{c}95 \% \text { Limits of } \\
\text { agreement }\end{array}$ & $\%$ bias & $\begin{array}{c}\text { Precision, } \\
\%\end{array}$ & $\mathrm{CV}, \%$ & ICC & $\operatorname{Lin} \rho_{c}(95 \% \mathrm{CI})$ & Pearson $\mathrm{r}$ & $\begin{array}{c}\text { Bradley- } \\
\text { Blackwood F (P) }\end{array}$ \\
\hline \multirow{11}{*}{ 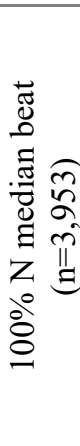 } & Heart rate, bpm & $61.5(9.4)$ & $61.7(9.4)$ & -0.23 & -5.5 to 5.0 & 0.34 & 99.66 & 4.3 & 0.979 & $0.958(0.956-0.961)$ & 0.959 & $15.0(<0.0001)$ \\
\hline & Peak QRS-Tangle, ${ }^{\circ}$ & $43.7(36.0)$ & $43.8(36.2)$ & -0.05 & -21.1 to 21.0 & 0.08 & 99.92 & 24.2 & 0.977 & $0.956(0.953-0.958)$ & 0.956 & $1.26(0.285)$ \\
\hline & Area QRS-Tangle, & $63.9(34.5)$ & $64.0(34.7)$ & -0.10 & -14.6 to 14.4 & 0.15 & 99.85 & 11.4 & 0.989 & $0.977(0.976-0.979)$ & 0.977 & $2.09(0.124)$ \\
\hline & Peak SVG azimuth, ${ }^{\circ}$ & $-1.4(26.9)$ & $-1.3(26.7)$ & -0.13 & -18.5 to 18.3 & 0.08 & 99.92 & 5.2 & 0.968 & $0.939(0.935-0.942)$ & 0.939 & $0.91(0.403)$ \\
\hline & Area SVG azimuth, & $-17.5(25.7)$ & $-17.0(25.8)$ & -0.53 & -21.4 to 20.4 & 0.38 & 99.62 & 6.4 & 0.955 & $0.914(0.909-0.919)$ & 0.914 & $5.26(0.005)$ \\
\hline & Peak SVG elevation, ${ }^{\circ}$ & $71.0(14.4)$ & $71.0(14.1)$ & -0.04 & -6.8 to 6.8 & 0.07 & 99.93 & 4.9 & 0.985 & $0.970(0.968-0.972)$ & 0.971 & $16.6(<0.0001)$ \\
\hline & Area SVG elevation, ${ }^{\circ}$ & $69.5(15.3)$ & $69.6(15.2)$ & -0.08 & -9.8 to 9.6 & 0.14 & 99.86 & 7.1 & 0.973 & $0.947(0.944-0.951)$ & 0.947 & $1.57(0.209)$ \\
\hline & Peak $\mathrm{SVG}_{\mathrm{mag}}, \mathrm{mV}$ & $1.57(0.45)$ & $1.56(0.45)$ & 0.001 & -0.21 to 0.21 & 0.06 & 99.94 & 6.8 & 0.985 & $0.971(0.969-0.973)$ & 0.971 & $0.08(0.926)$ \\
\hline & $\mathrm{SVG}, \mathrm{mV}{ }^{*} \mathrm{~ms}$ & $67.0(27.1)$ & $66.9(27.0)$ & 0.15 & -11.4 to 11.7 & 0.27 & 99.73 & 8.8 & 0.988 & $0.976(0.975-0.978)$ & 0.976 & $1.79(0.167)$ \\
\hline & VMQTi, mV*ms & $96.8(30.5)$ & $96.7(30.3)$ & 0.10 & -8.87 to 9.08 & 0.13 & 99.87 & 4.7 & 0.994 & $0.989(0.988-0.989)$ & 0.989 & $4.10(0.017)$ \\
\hline & SAIQRST, $\mathrm{mV}^{*} \mathrm{~ms}$ & $146.7(46.6)$ & $146.5(46.3)$ & 0.251 & -14.5 to 15.0 & 0.22 & 99.78 & 5.1 & 0.993 & $0.987(0.986-0.988)$ & 0.987 & $5.67(0.003)$ \\
\hline
\end{tabular}


Table 4. Reproducibility agreement of GEH metrics on two 10-sec ECGs, if $\leq 6,7-9, \geq 10 \mathrm{~N}$ beats included in $\mathrm{N}$ median beat.

\begin{tabular}{|c|c|c|c|c|c|c|c|c|c|c|c|c|}
\hline & Measurement & $\begin{array}{c}\text { ECG1 } \\
\text { mean(SD) }\end{array}$ & $\begin{array}{c}\text { ECG2 } \\
\text { mean(SD) }\end{array}$ & Bias & $\begin{array}{c}95 \% \text { Limits of } \\
\text { agreement }\end{array}$ & $\%$ bias & $\begin{array}{c}\text { Precision, } \\
\% \\
\end{array}$ & $\mathrm{CV}, \%$ & $\mathrm{ICC}$ & Lin $\rho_{c}(95 \% \mathrm{CI})$ & Pearson & $\begin{array}{l}\text { r Bradley- } \\
\text { Blackwood F (P) }\end{array}$ \\
\hline \multirow{11}{*}{ 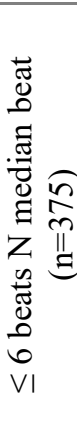 } & Heart rate, bpm & $47.6(4.4)$ & $47.7(4.3)$ & -0.08 & -4.65 to 4.49 & 0.19 & 99.81 & 4.7 & 0.922 & $0.855(0.826-0.880)$ & 0.856 & $0.26(0.768)$ \\
\hline & Peak QRS-Tangle, ${ }^{\circ}$ & $47.6(36.7)$ & $48.2(37.8)$ & -0.59 & -22.8 to 21.6 & 12.3 & 87.70 & 23.1 & 0.977 & $0.954(0.944-0.962)$ & 0.954 & $2.32(0.100)$ \\
\hline & Area QRS-Tangle, ${ }^{\circ}$ & $67.9(35.9)$ & $68.8(36.5)$ & -0.86 & -16.0 to 14.3 & 4.05 & 95.95 & 11.2 & 0.989 & $0.977(0.972-0.981)$ & 0.977 & $3.56(0.029)$ \\
\hline & Peak SVG azimuth, ${ }^{\circ}$ & $-0.3(24.4)$ & $0.4(24.8)$ & -1.45 & -22.2 to 19.3 & 0.41 & 99.59 & 2.9 & 0.988 & $0.976(0.971-0.981)$ & 0.977 & $4.58(0.011)$ \\
\hline & Area SVG azimuth, ${ }^{\circ}$ & $-20.9(28.0)$ & $-19.6(28.8)$ & -1.31 & -40.8 to 38.2 & 0.66 & 99.34 & 11.7 & 0.957 & $0.748(0.700-0.789)$ & 0.749 & $1.18(0.310)$ \\
\hline & Peak SVG elevation, ${ }^{\circ}$ & $72.0(14.8)$ & $72.4(14.4)$ & -0.43 & -5.41 to 4.55 & 0.56 & 99.44 & 3.5 & 0.993 & $0.984(0.981-0.987)$ & 0.985 & $11.27(<0.0001)$ \\
\hline & Area SVG elevation, ${ }^{\circ}$ & $70.2(17.4)$ & $70.4(16.4)$ & -0.20 & -10.4 to 10.0 & 0.25 & 99.75 & 7.4 & 0.977 & $0.953(0.943-0.961)$ & 0.954 & $6.83(0.001)$ \\
\hline & Peak $\mathrm{SVG}_{\mathrm{mag}, \mathrm{mV}}$ & $1.62(0.48)$ & $1.61(0.48)$ & 0.011 & -0.29 to 0.31 & 0.97 & 99.03 & 9.2 & 0.975 & $0.950(0.938-0.959)$ & 0.950 & $1.09(0.338)$ \\
\hline & $\mathrm{SVG}, \mathrm{mV}^{*} \mathrm{~ms}$ & $76.6(32.2)$ & $76.1(32.4)$ & 0.51 & -12.7 to 13.8 & 1.25 & 98.75 & 8.4 & 0.989 & $0.978(0.973-0.982)$ & 0.978 & $1.24(0.291)$ \\
\hline & VMQTi, mV*ms & $112.0(36.4)$ & $111.7(37.0)$ & 0.31 & -11.6 to 12.2 & 0.43 & 99.57 & 5.3 & 0.993 & $0.986(0.983-0.989)$ & 0.986 & $2.10(0.124)$ \\
\hline & SAIQRST, $\mathrm{mV}^{*} \mathrm{~ms}$ & $168.2(53.9)$ & $167.8(54.8)$ & 0.42 & & & 99.59 & 5.5 & 0.992 & $0.985(0.981-0.988)$ & 0.985 & $2.17(0.115)$ \\
\hline \multirow{11}{*}{ 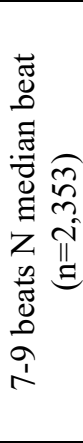 } & Heart rate, bpm & $60.0(4.6)$ & $60.3(4.6)$ & -0.25 & -5.02 to 4.52 & 0.35 & 99.65 & 3.9 & 0.925 & $0.859(0.848-0.869)$ & 0.860 & $12.8(<0.0001)$ \\
\hline & Peak QRS-Tangle, ${ }^{\circ}$ & $41.7(34.5)$ & $41.6(34.4)$ & 0.16 & -19.2 to 19.5 & 0.44 & 99.56 & 23.4 & 0.979 & $0.959(0.956-0.962)$ & 0.959 & $0.32(0.723)$ \\
\hline & Area QRS-Tangle, ${ }^{\circ}$ & $61.6(33.1)$ & $61.6(33.2)$ & -0.003 & -13.1 to 13.1 & 0.006 & 99.99 & 10.7 & 0.990 & $0.980(0.978-0.981)$ & 0.980 & $0.58(0.562)$ \\
\hline & Peak SVG azimuth, ${ }^{\circ}$ & $-2.4(25.7)$ & $-2.5(25.0)$ & 0.12 & -18.2 to 18.4 & 0.07 & 99.93 & 5.2 & 0.965 & $0.932(0.927-0.937)$ & 0.933 & $6.24(0.002)$ \\
\hline & Area SVG azimuth, ${ }^{\circ}$ & $-18.6(24.5)$ & $-18.5(24.4)$ & -0.17 & -9.0 to 8.7 & 0.11 & 99.89 & 2.8 & 0.991 & $0.983(0.981-0.984)$ & 0.983 & $3.26(0.038)$ \\
\hline & Peak SVG elevation, ${ }^{\circ}$ & $70.5(14.3)$ & $70.5(13.8)$ & 0.033 & -7.3 to 7.4 & 0.04 & 99.94 & 5.3 & 0.982 & $0.965(0.962-0.967)$ & 0.965 & $20.1(<0.0001)$ \\
\hline & Area SVG elevation, ${ }^{\circ}$ & $69.1(14.9)$ & $69.1(14.8)$ & & & & & 6.4 & 0.977 & & 0.955 & $2.37(0.094)$ \\
\hline & Peak $\mathrm{SVG}_{\mathrm{mag}}, \mathrm{mV}$ & $1.58(0.44)$ & $1.59(0.44)$ & -0.002 & -0.2 to 0.2 & 0.13 & 99.87 & 6.5 & 0.986 & $0.973(0.971-0.975)$ & 0.973 & $0.44(0.642)$ \\
\hline & $\mathrm{SVG}, \mathrm{mV}^{*} \mathrm{~ms}$ & $69.0(25.7)$ & $69.0(25.5)$ & & -11.2 to 11.2 & & 99.97 & & 0.987 & $0.975(0.973-0.977)$ & 0.975 & $1.18(0.309)$ \\
\hline & VMQTi, mV*ms & $97.9(29.7)$ & $97.8(29.4)$ & 0.08 & -8.59 to 8.74 & 0.09 & 99.91 & 4.5 & 0.994 & $0.989(0.988-0.990)$ & 0.989 & $7.26(0.0007)$ \\
\hline & SAIQRST, $\mathrm{mV}^{*} \mathrm{~ms}$ & $148.8(45.6)$ & $148.6(45.0)$ & 0.21 & -14.3 to 14.7 & 0.17 & 99.83 & 5.0 & 0.993 & $0.987(0.986-0.988)$ & 0.987 & $8.24(0.0003)$ \\
\hline \multirow{11}{*}{ 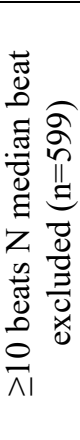 } & Heart rate, bpm & $76.6(6.2)$ & $76.9(6.2)$ & -0.24 & -5.6 to 5.1$)$ & 0.32 & 99.68 & 3.5 & 0.949 & $0.902(0.886-0.916)$ & 0.903 & $2.35(0.096)$ \\
\hline & Peak QRS-Tangle, ${ }^{\circ}$ & $50.5(40.9)$ & $50.2(40.7)$ & 0.26 & -21.2 to 21.7 & & 96.50 & 21.6 & 0.982 & $0.964(0.958-0.969)$ & 0.964 & $0.27(0.760)$ \\
\hline & Area QRS-Tangle, ${ }^{\circ}$ & $73.0(37.8)$ & $72.3(37.9)$ & 0.69 & & 4.0 & 96.00 & 10.3 & 0.990 & $0.980(0.976-0.983)$ & 0.980 & $2.54(0.079)$ \\
\hline & Peak SVG azimuth, ${ }^{\circ}$ & $2.1(32.3)$ & $2.6(33.1)$ & -0.53 & -20.2 to 19.2 & 0.31 & 99.69 & 5.4 & 0.976 & $0.952(0.944-0.959)$ & 0.953 & $2.75(0.06)$ \\
\hline & Area SVG azimuth, ${ }^{\circ}$ & $-11.7(28.7)$ & $-11.2(27.7)$ & -0.55 & -16.7 to 15.6 & 0.33 & 99.67 & 4.9 & 0.979 & $0.957(0.950-0.963)$ & 0.958 & $5.89(0.003)$ \\
\hline & Peak SVG elevation, ${ }^{\circ}$ & $71.5(15.3)$ & $71.4(15.5)$ & 0.085 & 06.3 to 6.5 & 0.12 & 99.88 & 4.5 & 0.989 & $0.977(0.973-0.981)$ & 0.977 & $1.26(0.28)$ \\
\hline & Area SVG elevation, ${ }^{\circ}$ & $70.6(16.4)$ & $70.7(16.4)$ & -0.06 & -11.2 to 11.1 & 0.08 & 99.92 & 7.9 & 0.969 & $0.940(0.930-0.949)$ & 0.940 & $0.04(0.963)$ \\
\hline & Peak $\mathrm{SVG}_{\mathrm{mag}}, \mathrm{mV}$ & $1.46(0.42)$ & $1.46(0.42)$ & -0.001 & -0.18 to 0.18$)$ & 0.05 & 99.95 & 6.1 & 0.989 & $0.977(0.973-0.981)$ & 0.977 & $0.45(0.640)$ \\
\hline & $\mathrm{SVG}, \mathrm{mV}^{*} \mathrm{~ms}$ & $53.3(22.1)$ & $53.3(21.9)$ & -0.03 & -10.9 to 10.9 & 0.04 & 99.96 & 10.4 & 0.984 & $0.968(0.963-0.973)$ & 0.968 & $0.30(0.742)$ \\
\hline & VMQTi, mV*ms & $85.0(25.9)$ & $85.0(25.7)$ & 0.08 & -7.8 to 7.9 & 0.09 & 99.91 & 4.7 & 0.994 & $0.988(0.986-0.990)$ & 0.988 & $0.66(0.515)$ \\
\hline & SAIQRST, $\mathrm{mV}^{*} \mathrm{~ms}$ & $128.8(39.9)$ & $128.6(39.6)$ & 0.19 & -12.6 to 12.9 & 0.15 & 99.85 & 5.1 & 0.993 & $0.987(0.984-0.989)$ & 0.987 & $1.24(0.290)$ \\
\hline
\end{tabular}




\section{Figure legends:}

Figure 1. GEH measurements. (A) Spatial ventricular gradient (SVG) vector (blue) obtained as a vector sum of QRS (green) and T vector (red). Spatial QRS-T angle is the 3D angle between QRS and T vector. (B) Orientation of the angles (azimuth and elevation) in 3D space. (C) Sum absolute QRST integral (SAIQRST). (D) Vector magnitude QT integral.

Figure 2. Study flowchart.

Figure 3. Bland-Altman plots demonstrating agreement of spatial area QRS-T angle on two ECGs. Median beats were constructed in $(\mathbf{A})$ normal sinus $(\mathrm{N})$ rhythm, $(\mathbf{B})$ atrial fibrillation/flutter, (C) ventricular pacing, including $(\mathbf{D}) \leq 6 \mathrm{~N}$ beats, $(\mathbf{E}) 7-9 \mathrm{~N}$ beats, $(\mathbf{F}) \geq 10 \mathrm{~N}$ beats. The scatterplot presents paired differences (Y-axis), plotted against pair-wise means (Xaxis). The reference line indicates the perfect average agreement, $\mathrm{Y}=0$. The central green line indicates the mean difference between the two measurements, or mean bias. Upper and lower lines represent the mean \pm 2 standard deviations (SD), or $95 \%$ limits of agreement.

Figure 4. (A). Bland-Altman plot demonstrating agreement of mean-centered logtransformed SAIQRST and VMQTi. Definitions given in Figure 3 legend. (B). Concordance scatterplot of the mean-centered log-transformed SAIQRST and VMQTi. The reduced major axis of the data (green) goes through the intersection of the means and has the slope given by the sign of Pearson's $r$ and the ratio of the standard deviations. The reference red line shows the perfect concordance, $\mathrm{Y}=\mathrm{X}$. 


\section{Figure 1:}

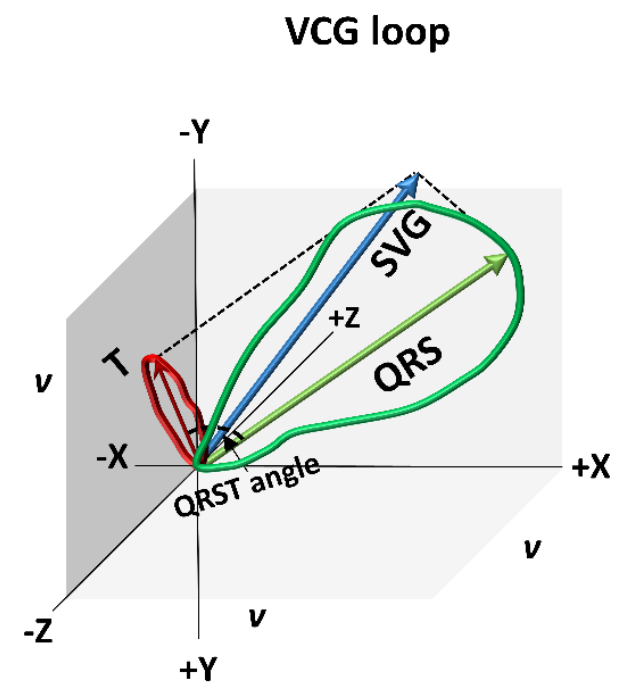

\section{Sum absolute QRST integral}
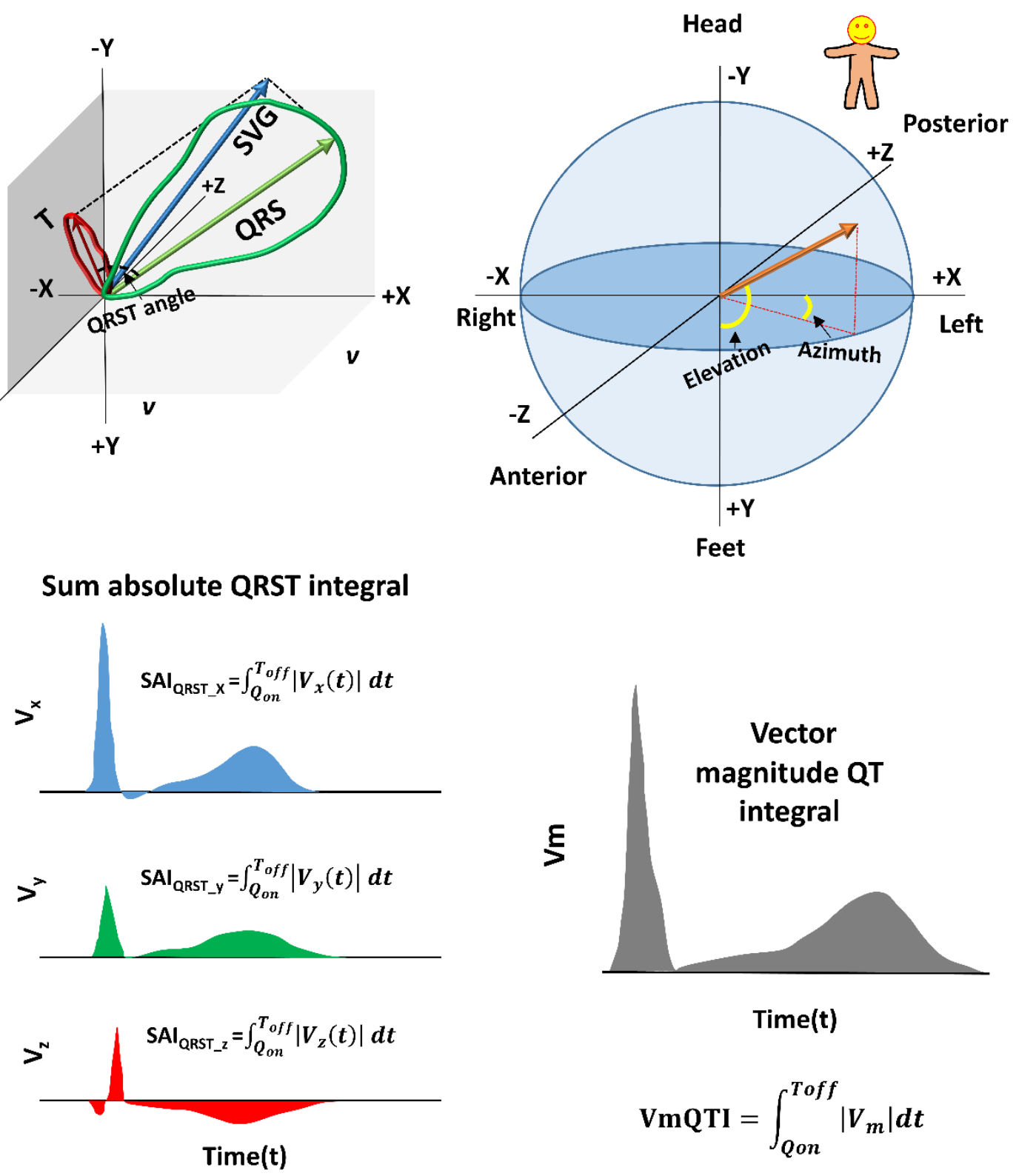

$\mathrm{SAI} \mathrm{QRST}=\mathrm{SAI}_{\mathrm{QRST}_{-} \mathrm{x}}+\mathrm{SAI}_{\mathrm{QRST}_{-} y}+\mathrm{SAI}_{\mathrm{QRST}_{-} z}$ 


\section{Figure 2:}

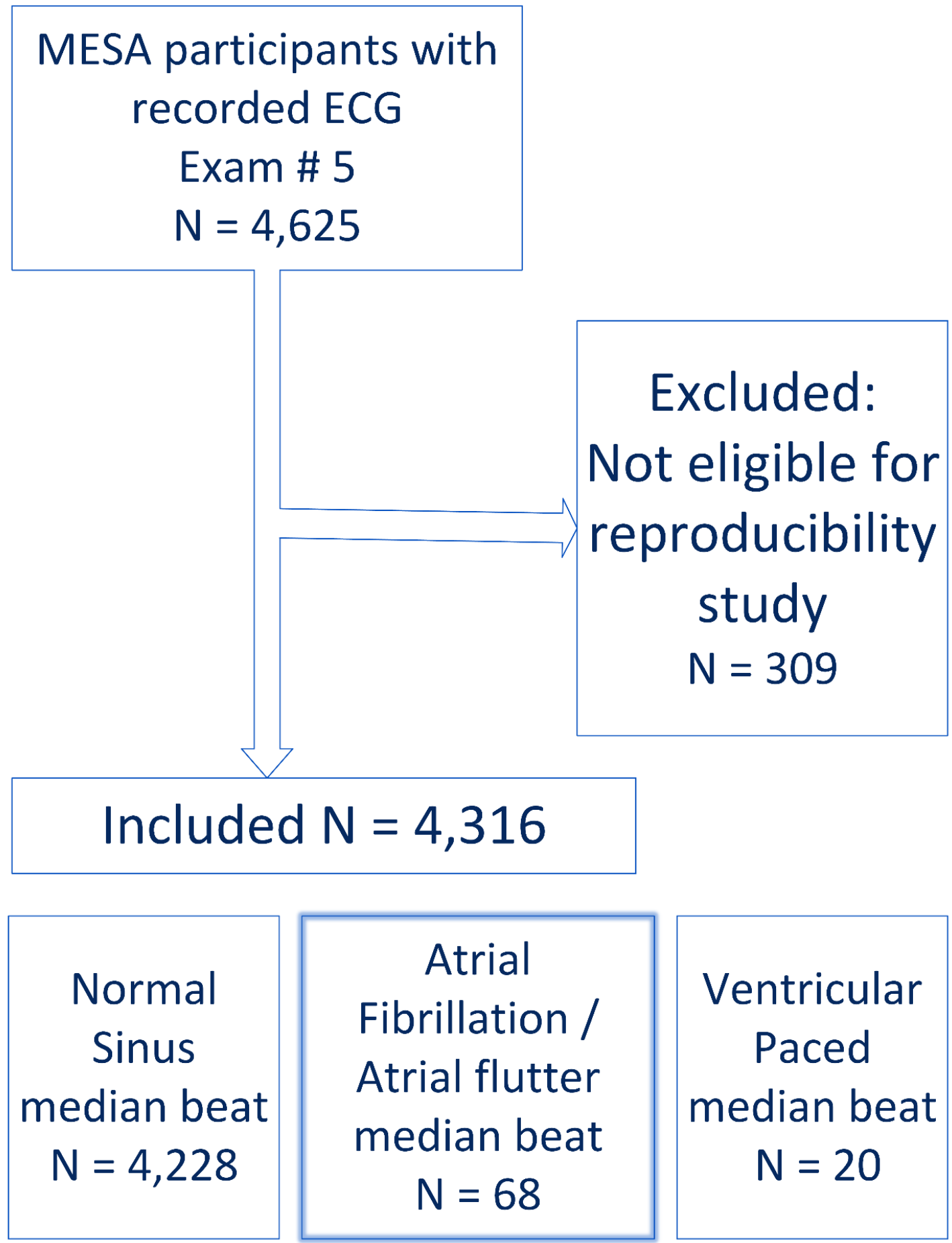


Figure 3:

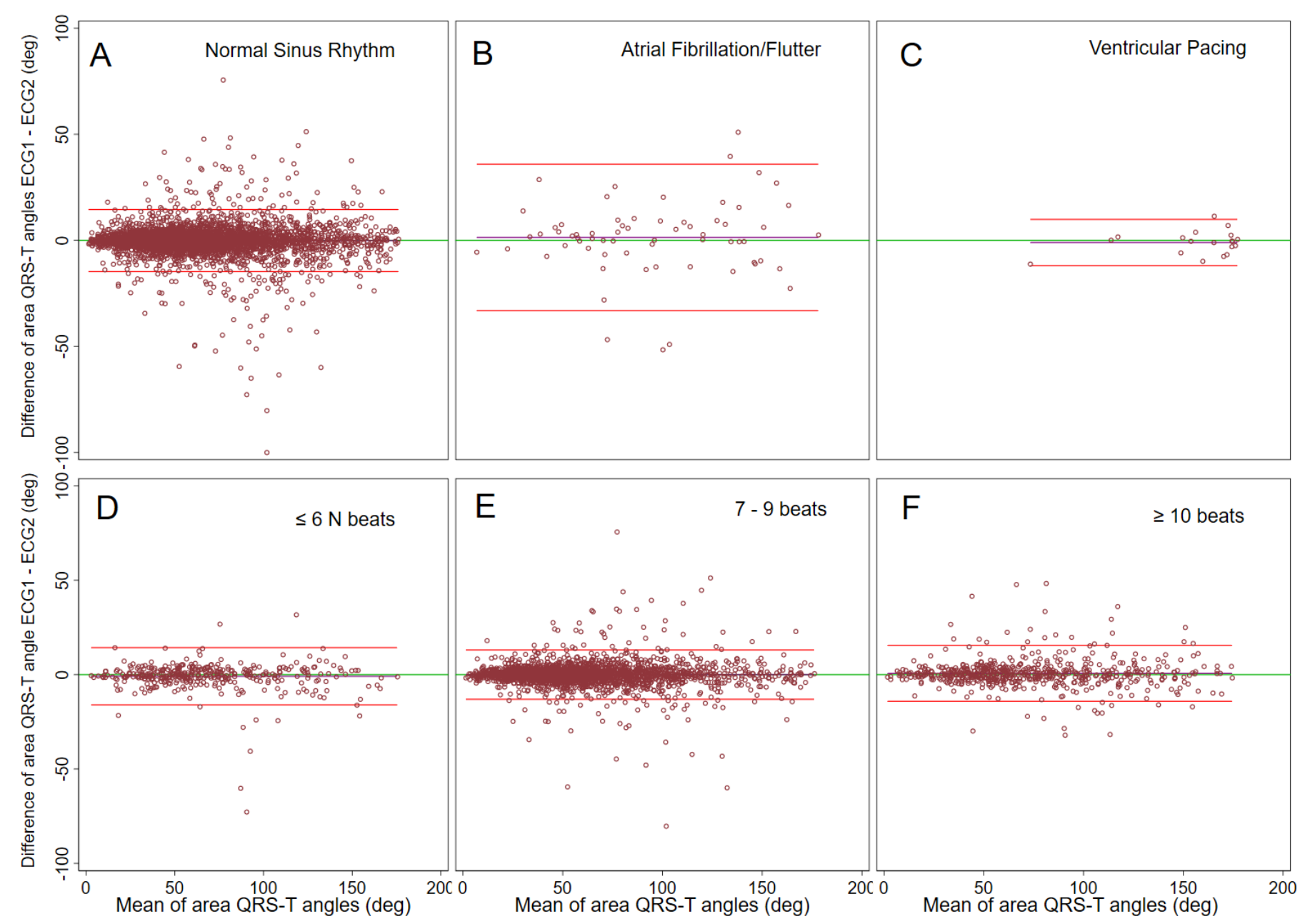


Figure 4:
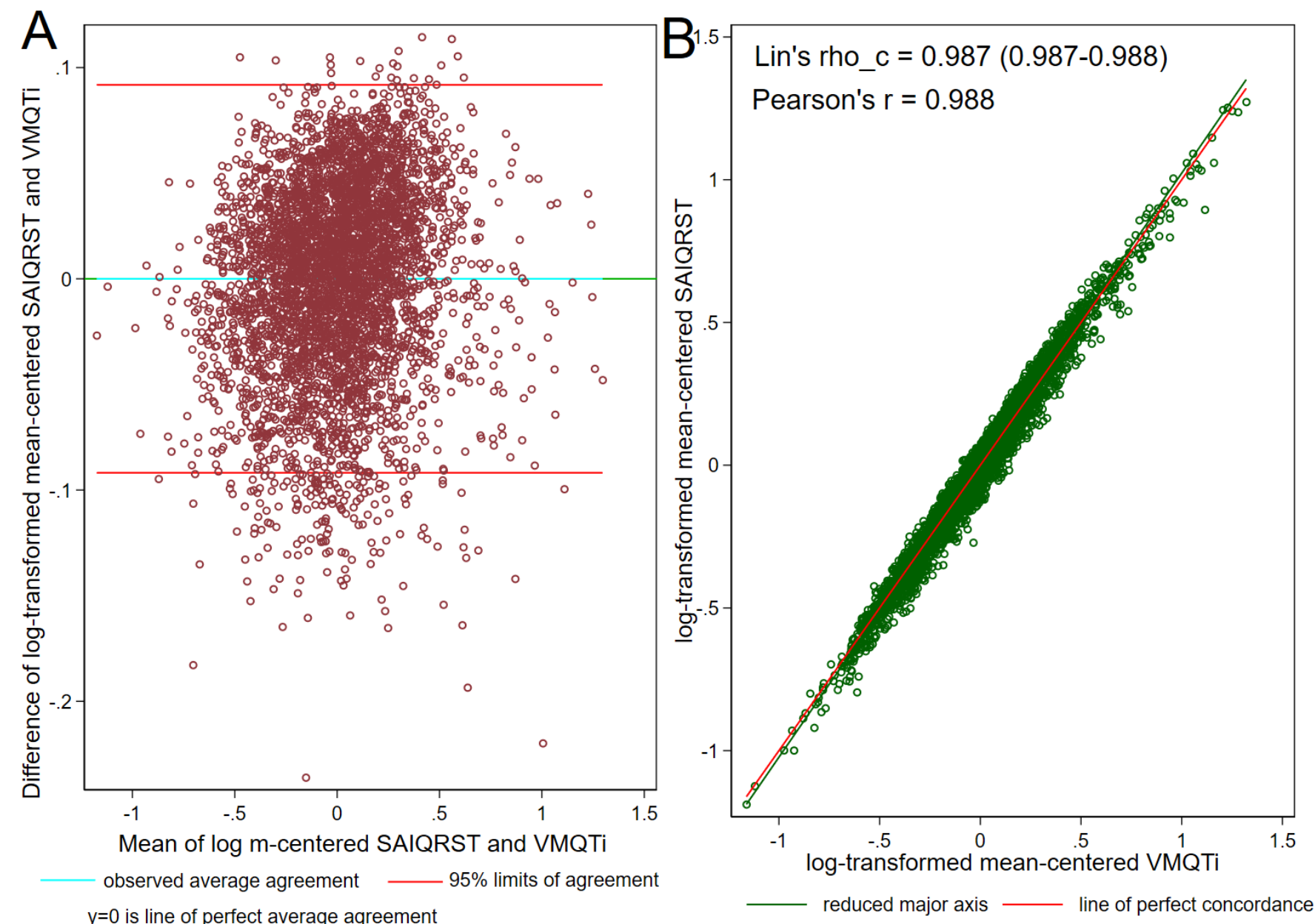